\title{
ANALISIS SISTEM INFORMASI MANAJEMEN ORGANISASI BERBASIS KOMPUTER SEBAGAI PENGAMBILAN KEPUTUSAN PERUSAHAAN DAN ORGANISASI
}

\author{
Rahayu Sri Utami ${ }^{1}$, Alda ${ }^{2}$, Fauziah Fitri Tanjung ${ }^{3}$ \\ Departemen Manajemen Informatika, AMIK WIDYALOKA Pakam \\ ${ }^{1}$ Jl.Duku II No.25 Perumnas BSP Kecamatan Lubuk Pakam Kabupaten Deli Serdang Propinsi \\ Sumatera Utara Indonesia* \\ Departemen Manajemen Informatika, AMIK WIDYALOKA Pakam \\ ${ }^{2}$ Dusun IV Panati Labupekan Kecamatan Pantai Labu Kabupaten Deli Serdang Propinsi Sumatera \\ Utara Indonesia* \\ Departemen Manajemen Informatika, AMIK WIDYALOKA Pakam \\ ${ }^{3}$ Jl.Kutilang Dsn IV Citaman Jernih Kecamatan Perbaungan Kabupaten Serdang Bedagai Propinsi \\ Sumatera Utara Indonesia* \\ rahayu.sriutami891@gmail.com, alda.17adm@gmail.com,fitritanjungfauziah@gmail.com
}

\begin{abstract}
Abstrak
Dalam perusahaan/organisasi sistem informasi manajemen akan memberikan banyak manfaat bila digunakan sebaik mungkin.peran manajemenlah yang harus melakukan peenyebaran dan penggunaan sumber-sumber secara efektif dan efisien untuk mencapai suatu tujuan dengan diterimanya suatu informasi yang cepat, tepat dan akurat akan Manajemen Berbasis Komputer sangat diperlukan untuk mendukung tujuan organisasi tersebut. Dalam suatu perusahaan tidak terlepas dari berbagai macam masalah yang ada didalam organisasi, dan didalam suatu perusahaan, perubahan sering timbul, sehingga perubahan ini sering sekali menjadi hambatan bagi manajer dan menimbulkan masalah dalam mengambil keputusan. Sistem informasi manajemen berbasis computer tidak hanya memproses data menjadi informasi tetapi juga menyalurkan informasi untuk mendukung proses pengambilan keputusan.
\end{abstract}

Kata Kunci : Sistem, Informasi, Manajemen, Komputer, Keputusan

Abstract: In a company/organization managemen information system will give you many benefits when used as best as possible. The management roles should do the deployment and use of sources in affective and efficient way to achieve a goal, with the receipt of any information that is fast, precise and accurate would greatly help fucation manajemen. Therefore the computer based management information sytem is needed to support the objectives of the organization, in an enterprise will not be in spite of the various problems that exixt in an enterprise will not be in spite of the varios problems that exixt in the Organization, and in a coporation, change often arise, so this change is often a barrier for managers and cause problems in decision making. Computer-based management information systems not only process data into information but also distributes information to support the decision making process.

Keywords : Management, Information Systems, Computer Science, Decision.

PENDAHULUAN 


\subsection{Latar Belakang}

Apabila berbicara tentang sistem Informasi Manajemen, maka yang diingat adalah computer dengan sebuah sistem yang saling tersambung dengan berbagai jaringan dalam computer tersebut. Persepsi seperti ini tentu saja tidaklah semuanya benar, karena teknologi computer hanyalah sebuah wadah atau fasilitas. Salah satu fungsi manajemen adalah perencanaan. Dalam proses perencanaan, pihak manajemen berusaha memikirkan apa saja yang akan dikerjakannya, berupa ukuran atau jumlahnya, siapa yang akan melaksanakan dan mengendalikannya agar tujuan organisasi/perusahaan dapat tercapai. Dalam kerangka itu semua, diperlukan informasi, dan informasi yang relevan dengan proses perencanaan harus disediakan. Alat untuk menyediakan informasi tersebut dapat berupa sebuah SIM, atau dapat juga usaha khusus seperti pengumpulan data baik internal maupun eksternal, yang nantinya dapat menghasilkan informasi yang dibutuhkan dan memberikan kontribusi pada kinerja pemakai. Jadi, informasi adalah bahan dasar bagi pimpinan organisasi atau manejer dalam membuat rencana, merumuskan kegiatan atau mengambil kebijakan.

Teknologi informasi banyak membawa perubahan dalam organisasi dan proses bisnis, teknologi informasi merupakan suatu kebutuhan bagi organisasi yang dapat membantu kinerja organisasi dan individu. Sistem informasi akan membantu perusahaan untuk menyajikan laporan keuangan ke dalam bentuk informasi yang akurat dan terpercaya, sehingga banyak pihak yang memanfaatkan sistem informasi akutansi untuk mencapai keunggulan bagi perusahaan. Sistem informasi adalah komponen dan elemen dari suatu organisasi yang menyediakan informasi bagi pengguna dengan pengolahan peristiwa keuangan (Zare, 2012).

Semua organisasi membutuhkan aliran informasi yang membantu manajer untuk mengambil bermacam keputusan yang dibutuhkan. Aliran informasi ini diatur dan siarahkan dalam suatu sistem informasi. Sistem informasi berperan dalam proses pengambilan keputusan operasional harian sampai perencanaan jangka panjang. Sebelum computer ada, sistem informasi sudah menjadi kebutuhan organisasi. Ini berarti sistem informasi tidak selamanya berbasis komputer.. namun dengan berkembangnya fungsi komputer, sistem informasi organisasi digunakan untuk mendukung aktifitas-aktifitas organisasi berkembang dari masa ke masa. Tingkat keterlibatan sistem informasi organisasi makin lama makin luas dan dalam.

Tujuan dari penelitian ini untuk memperbaiki SDM dalam sistem informasi dengan cepat dan tepat. Untuk mengatasi masalah yang ada didalam organisasi dan didalam suatu perusahaan. Sistem Infomasi Manajemen (SIM). Berfungsi sebagai peningkatan kinerja organisasi yang ditutut untuk mengikuti perkembangan teknologi berbasis computer dalam upayah pengambilan keputusan peran manajemen yang paling penting, tersedianya sumber informasi yang reliable merupakan komponen kunci bagi pembuatan keputusan manajemen.

Manfaat dari penelitian ini untuk memperbaiki kualitas SDM (sember daya manusia) yang lebih berkompeten khususnya dibidang computer. Yang harus mengikuti perkembangan dan persaingan teknologi informasi (teknologi computer) yang semakin hari kian semakin berkembang dalam penyampaikan informasi maupun menerima informasi.

\section{Kajian Pustaka Sistem informasi}

Sudut pandang teknis, sistem informasi yaitu mengumpulkan menyimpan dan menyebarkan informasi untuk mendukung fungsi organisasi . contoh dari fungsi organisasi 
adalah pencatatan, pengambilan keputusan komunikasi , koordinasi, pengawasan, analisis data dan visual data. Penggunaan teknologi informasi sangat penting untuk mendukung fungsi organisasi, computer adalah teknologi yang dapat mendukung sistem informasi. Sistem informasi berbasis computer dapat digunakan untuk memberikan informasi mengenai manajemen, akutansi, decision support system, kantor virtual dan sistem berbasis pengetahuan.

Menurut Jogianto (2005) sistem informasi manajemen merupakan penerapan sistem informasi di dalam organisasi untuk mendukung informasi yang dibutuhkan oleh semua tingkatan manajemen. Menurut Raymond (2011) sistem informasi manajemen sebagai sistem informasi berbasis computer yang menyediakan informasi bagi para pengguna yang memeliki kebutuhan yang sama. Berdasarkan pengertian sistem informasi manajemen dapat disimpulkan bahwa sistem informasi manajemen dapat disimpulkan bahwa sistem manajemen adalah penerapan sistem informasi berbasis komnputer untuk menyediakan informasi yang dibutuhkan oleh semua tingkatan manajemen.

Tujuan Sistem Informasi Manajemen (SIM) adalah memberikan informasi untuk pembuatan keputusan dalam merencanakan, memulai, mengatur dan mengendalikan operasi sub-sistem dari perusahaan dan untuk memeberikan sinergi perusahaan dalam proses operasioanal.

Stair (dalam Al Fatta, 2007) sistem informasi berbasis computer dalam suatu organisasi terdiri dari komponen-komponen diataranya, perangkat keras, perangkat lunak, database, telekomunikasi, manusia, dan prosedur. Perangkat keras berfungsi untuk input data, memproses data dan keluaran data. Perangkat lunak adalah program yang diberikan ke computer. Database adalah kumpulan data dan informasi yang diorganisasikan sehingga mudah diakses oleh pengguna sistem.

a. Sistem

beberapa pengertian atau definisi mengenai sistem yang diberikan oleh para ahli sebagai bahan perbandingan antara lain sebagai berikut :

a. Sistem adalah satu kesatuan komponen yang saling terhubung dengan batasan yang jelas berkerja bersama-sama untuk mencapai seperangkat tujuan (O’Brien dan Marakas 2009).

b. Pengertian sistem menurut Kadir $(2003 ; 54)$ sistem adalah sekumpulan elemen yang saling terkait atau terpadu yang dimaksudkan untuk mencapai tujuan.

b.Tujuan Sistem Informasi

Tujuan dari sistem informasi adalah menghasilkan infomasi data yang diolah menjadi bentuk yang berguna bagi para pemakainya untuk dapat berguna maka informasi harus didukung oleh tiga pilar sebagai berikut : tepat kepada orangnya atau relevan, tepat waktu dan tepat nilainya atau akurat. Keluaran yang tidak didukung oleh tiga pilar ini tidak dapat dikatakan sebagai informasi yang berguna. Untuk menjadi sistem informasi, maka hasil dari sistem itu harus berupa informasi yang berguna, yaitu harus memenuhi ketiga criteria ; relevan, tepat waktu dan akurat (Usman, 2000).

Semua organisasi membutuhkan aliran informasi yang membantu manajer untuk mengambil bermacam keputusan yang dibutuhkan. Aliran informasi ini diatur dan diarahkan dalam suatu sistem informasi. Sistem informasi berperan dalam proses pengambilan keputusan operasional harian sampai perencanaan jangka panjang. Sebelum computer ada, sistem informasi sudah adalah sudah menjadi kebutuhan organisasi. Ini berarti sistem informasi tidak selamanya berbasis computer. Namun dengan berkembangnya fungsi 
computer. Sistem informasi organisasi digunakan untuk mendukung aktifitas-aktifitas organisasi berkembang dari masa ke masa. Tingkat keterlibatan sistem informasi organisasi makin lama makin luas dan dalam.

\section{Pentingnya Sistem Informasi Manajemen}

Keberhasilan suatu organisasi dalam mencapai tujuannya sangat tergantung pada kemampuan orang yang mengelola organisasi tersebut. Manajemen sebagai suatu metode yang mengatur. Mengelola organisasi dapat diartikan sebagaib seni melaksanakan sesuatu melaluin orang. Jika manajemen suatu organisasi baik maka akan meningkatkan kemakmuran suatu negara.

Dalam menjalankan tugasnya, para manajer memerlukan informasi, karena adanya perbedaan tugas maka informasi yang diperlukan juga akan berbeda. Perbedaan tersebut disebabkan oleh adanya periode waktu, tingkat, ketidakpastian, tipe informasi, dasar kebutuhan informasi dan bentuk pelaporan. Sehingga dapat dikategorikan bahwa informasi adalah salah satu jenis sumber daya utama, dan termasuk dalam kategori sumber daya konseptual.

Sistem informasi meengandung tiga aktivitas dasar di dalamnya, yaitu aktivitas dasar di dalamnya, yaitu; aktivitas masukan (input), pemrosesan (processing), dan keluaran (output). Tiga aktivitas dasar ini menghasilkan informasi yang dibutuhkan organisasi untuk pengambilan keputusan, pengendalian operasi, analisis permasalahan, dan menciptakan produk atau jasa baru. Masukan berperan di dalam pengumpulan bahan mentah (raw data), baik yang diperoleh dari dalam maupun pengumpulan bahan mentah (raw data), baik yang diperoleh dari dalam maupun dari lingkungan sekitar organisasi. Pemrosesan berperan untuk mengkonversi bahan mentah menjadi bentuk yang lebih memiliki arti. Sedangkan, keluaran dimaksudkkan untuk menstrafer informasi yang diproses kepada pihak-pihak atau aktivitas yang akan menggunakan. Sistem informasi juga membutuhkan umpan balik (feedback), yaitu untuk dasar evaluasi dan perbaikan ditahap input berikutnya (Sutono,2007).

Raymond McLeod Jr (1996;54) mengemukakan bahwa SIM adalah sebagai suatu sistem berbasis computer yang menyediakan informasi bagi beberapa pemakai dengan kebutuhan serupa. Output informasi digunakan oleh manejer maupun non manejer dalam perusahaan untuk membuat keputusan dalam memecahkan masalah. Sedangkan meneurut Komaruddin dalam Effendy $(1988 ; 111)$ SIM adalah pendekatan yang terorganisir dan terencana untuk memberikan eksekutif bantuan informasi yang memberikan kemudahan bagi proses manajemen. Menurut O'Brien dan Marakas (2009) tujuan dari sistem informasi yang dipergunakan di dalam perhitungan harga pokok jasa, produk, dan tujuan lain yang diinginkan manajemen, menyediakan informasi yang dipergunakan dalam perencanaan, pengendalian, pengevaluasian, dan perbaikan berkelanjutan; menyediakan informasi untuk pengambilan keputusan. Ketiga tujuan tersebut menunjukan bahwa manajer dan penggunan lainnya perlu memiliki akses ke informasi akutansi manajemen dapat membantu merekan mengindentifikasi suatu masalah, menyelesaikan masalah, dan mengevaluasi kinerja (informasi akutansi dibutuhkan dan dipergunakan dalam tahap manajemen, termasuk perencanaan, pengendalian dan pengambilan keputusan.

\section{Manajemen}

Setiap manusia dalam perjalanan hidupnya tidak akan terlepas dari namanya organisasi, dan di dalam organisasi itu dipelajarilah bagaimana cara mengelola organisasi dengan profesional, ini menunjukan ilmu manajemen bersifat universal. Oleh karena itu, salah satu cabang ilmu yang saat ini sangat berkembang pesat adalah ilmu manajemen, ilmu 
ini telah melakukan intervensi keberbagai bidang ilmu lain, atau paling tidak menggandeng ilmu lain dalam pengembangnnya. Kita kenal manajemen sumber daya manusia industry, manajemen keuangan, pemasaran, produksi, manajemen perkotaan, manajemen pemerintahan, manjemen pendidikan, manajemen sistem informasi, sistem informasi manajemen sampai kepada qolbu yang dikembangkan oleh Abdullah Gymnastiar. Menurut At-mosudirjo $(1986 ; 158)$, secara umum pengertian manajemen adalah pengendalian dan pemanfaatan dari pada semua factor dan sumber daya yang menurut suatu perencanaan (planning), diperlukan untuk mencapai atau menyelesaikan suatu prata (objective) atau tujuan-tujuan tertentu. Sedangkan menurut Siagian (1989;5) manajemen dapat didefinisikan sebagai kemampuan atau keterampilan untuk memperoleh sesuatu hasil dalam rangka pencapaian tujuan melalui kegiatan-kegiatan orang lain. Menutut Terry dalam Manullang $(2005 ; 1)$ manajemen adalah pencapaian tujuan yang ditetapkan terlebih dahulu dengan mempergunakan kegiatan orang lain. Menurut kamus besar bahasa Indonesia (KBBI) manajemen adalah penggunaan sumber daya secara efektif untuk mencapai sasaran atau pimpinan yang bertanggung jawab atas jalannya perusahaan dan organisasi. Dari definisidefinisi tersebut di atas, ada tiga hal penting dalam definisi-definisi tersebut. Pertama, ada tujuan yang hendak dicapai memerlukan/membutuhkan tenaga orang lain; dan ketiga, kegiatan/aktifitas orang lain tersebut harus dibimbing dan diawasi atau dikontrol.

\section{Komputer}

Komputer berasal dari kata latin computer yang mengandung arti menghitung. Karena luasnya bidang garapan ilmu computer, para pakar dan peneliti sedikit berbeda dalam mendefinisikan terminology komputer. Menurut Hamacher computer adalah mesin penghitung elektroonik yang cepat dan dapat menerima informasi input digital, kemudian memprosesnya sesuai dengan program yang tersimpan di memorinya, dan menghasilkan output berupa informasi. Blissmer mengatakan bahwa, computer adalah suatu alat elektronik yang mampu melakukan beberapa tugas sebagai berikut: menerima imput, memproses input tadi sesuai dengan programnya, menyimpan perintah-perintah dan hasil dari pengolahan, menyediakan output dalam bentuk informasi. Sedangkan Fuori berpendapat bahwa computer adalah suatu pemroses data yang dapat melakukan manusia kedalam computer melalui alat input, yang mengolahnya melalui cara tertentu, yang dapat dibedakan menjadi cara analoq dan digital

\section{Manusia dan Komputer.}

Pada awalnya dalam konsep sistem informasi tradisional, manusia merupakan komponen utama dalam mengolah data menjadi informasi. Kapasitas manusia dalam menerima masukan dan menghasilkan keluaran adalah terbatas. Dunia menyediakan lebih banyak masukan ini sampai batas jumlah yang dapat diatasi melalui suatu proses penyaringan atau seleksi. Digunakannya computer dalam sebuah sistem informasi menutupi kekurangankekurangan manusia dalam melakukan pengelolaan data menjadi informasi. Pemakaian computer memiliki beberapa keunggulan, diantaranya adalah ;(1) Tingkat akurasi informasi yang dihasilkan cukup tinggi; (2) Efisiensi Sumber Daya Manusia; dan (3) Kemudahan Berinteraksi dengan Penggunaannya (Wahyono,2003).

Pembuatan Keputusan (definisi), jenis-jenis, tingkat pengambilan keputusan dan menganalisis keputusan

Salah satu kegiatan manajemen yang penting adalah memahami sistem sepenuhnya untuk mengambil keputusan-keputusan tepat yang akan dapat memperbaiki hasil sistem keseluruan dalam batas-batas tertentu.dengan demikian pengambilan keputusan adalah suatu 
proses pemilihan dari berbagai alternative baik kuantitatif untuk mendapat suatu alternative terbaik guna menjawab masalah atau menyelesaikan konflik (pertentangan). Proses penurunan suatu keputusan mengandung empat unsure :

1) Model : Model menunjukkan gambaran suatu masalah secara kuantitatif atau kualitatif.

2) Kriteria : Kriteria yang dirumuskan menunjukkan tujuan dari keputusan yang diambil. Jika terdapat beberapa criteria yang saling bertentangan, maka pengambilan keputusan harus melalui kompromi (misalnya menambah jasa langganan dan mengurangi persediaan, maka keputusan mana yang diambil perlu kompromi).

3) Pembatas : factor-faktor tambahan yang perlu diperlihatkan dalam memecahkan masalah pengambilan keputusan. Misalnya dana yang kurang tersedia.

4) Optimalisasi : apabila masalah keputusan telah diuraikan dengan sejelas-jelasnya (mode), maka manajer menentukan apa yang diperlukan (criteria) dan apa yang diperbolehkan (pembatas). Pada keadaan ini pengambil keputusan siap untuk memilih pemecahan yang terbaik atau yang optimum.

\section{Tingkat-tingkat Pengambilan Keputusan}

Pengambilan keputusan berkisar dari sangat rutin dan baku (terprogram) sampai kompleks (tidak terprogram). Untuk maksud klasifikasi, maka pada dasarnya ada tiga tingkat pengambilan keputusan.

(1). Pengambilan keputusan tingkat strategis pengambilan keputusan strategis dicirikan oleh sejumlah besar ketidak pastian dan berorientasi ke masa depan. Keputusan-keputusan ini menetapkan rencana jangka panjang yang akan mempengaruhi keseluruan.organisasi. pengambilan keputusan tingkat strategis misalnya perluasan pabrik, penentuan produksi, penggabungan, penggolongan, pengeluaran modal dan sebagainya. Secara singkat dapat dikatakan bahwa strategi yang diputuskan itu berhubungan dengan perencanaan jangka panjang dan meliputi penentuan tujuan, penentuan kebijaksanaan, pengorganisasian, dan pencapaian keberhasilan organisasi secara keseluruan.

(2). Pengambilan keputusan tingkat taktis. Pengambilan keputusan taktis berhubungan dengan kegiatan jangka pendek dan penentuan sumber daya untuk mencapai tujuan. Jenis pengambilan keputusan berhubungan dengan bidang-bidang seperti perumusan anggaran, analisis ariran dana, penentuan tata ruang pabrik, masalah kepegawaian, perbaikan produksi serta penelitian dan pengembangan. Bila pengambilan keputusan strategi sebagian besar mengandung kegiatan perencanaan yang menyeluruh, pengambilan keputusan strategi sebagian besar mengandung kegiatan perencanaan dan pengawasan. Jenis keputusan ini memiliki potensi yang kecil untuk melaksanakan pengambilan keputusan terprogram. Untuk sebagian besar aturan-aturan keputusan dalam pengambilan keputusan taktis tidak tersusun dan tidak dapat dipertanggung jawabkan terhadap kebiasaan sehari-hari dan peraturan yang mengatur sendiri.

(3) Pengambilan keputusan tingkat teknis. Pada tingkat teknis, standar-standar ditentukan dan output bersifat deterministic (sifatnya menentukan). Pengambilan keputusan teknis adalah suatu proses yang dapat menjamin bahwa tugas-tugas spesifik dapat dilaksanakan dalam cara efektif dan efisien. Tingkat ini lebih ditekankan pada fungsi pengawasan dan sedikit sekali fungsi perencanaan. Pada tingkat ini pengambilan keputusan terprogram dapat dilaksanakan. Contoh jenis pengambilan keputusan ini adalah penerimaan atau penolakan kredit, pengendalian proses, penentuan waktu, penerimaan, pengiriman, pengawasan inventaris dan penempatan karyawan. 
Suatu tingkat pengambilan keputusan yang berlainan memerlukan jenis informasi yang berbeda pula. Para analisis harus menyadari jenis-jenis pengambilan keputusan ini di dalam sistem informasi guna memenuhi keperluan yang berbeda-beda, karena informasi yang akan dihasilkan tergantung kepada keperluan-keperluan ini. Perlu diperhatikan dan dipahami secara jelas bahwa dalam prakteknya di antara berbagai golongan pengambilan keputusan ini sering batas-batasan kabur malahan sering tumpang tindih. Walaupun garis-garis pemisahnya tidak jelas atau kabur, namun sebagai seorang analis harus menyadari akan adanya jenis-jenis pengambilan keputusan ini dan bagaimana sistem informasi dapat dirancang untuk memenuhi kebutuhan yang berlainan, sebab informasi yang dihasilkan oleh sistem informasi dapat dirancang untuk memenuhi kebutuhan yang berlainan, sebab informasi yang dihasilkan oleh sistem informasi akan tergantung kepada kebutuhan-kebutuhan ini

\section{Perkembangan Sistem Informasi Manajemen (SIM)}

Sesungguhnya, konsep sistem informasi telah ada sebelum munculnya komputer. Sebelum pertengahan abad ke-20, pada massa itu masih digunakan kartu punch, pemakaian computer terbatas pada aplikasi akutansi. Namun demikian para pengguna khususnya dilingkungan perusahaan masih mengesampingkan kebutuhan informasi bagi para manajer. Aplikasi akutansi yang berbasis computer tersebut diberi nama pengolahan data elektronik (PDE). Pada tahun 1964, computer generasi baru memperkenalkan prosesor baru yang menggunakan silicon chip circuitry dengan kemampuan pemrosesan yang lebih baik. Untuk mempromosikan generasi computer tersebut, para produsen memperkenalkan konsep sistem informasi manajemen dengan tujuan utama yaitu aplikasi computer adalah untuk menghasilkan informasi bagi manajemen.ketika itulah computer mampu mengisi kesenjanganalat bantu yang mampu menyediakan informasi manajemen. Konsep SIM ini sangat diterima beberapa perusahaan dan institusi pemerintah dengan skala besar seperti Departemen Keuangan khusus untuk menangani penyelenggaraan, pembiayaan dan penerimaan negara. Namun demikian, para pengguna yang mencoba SIM pada tahap awal menyadari bahwa penghalangan terbesar justru datang dari para lapisan manajemen tingkat menengah-atas.

\section{Pembahasan}

Kehadiran computer dalam sistem informasi manajemen telah memberikan banyak kemudahan bagi manajer dalam melakukan kegiatannya. Dari hal-hal yang kecil, seperti memberikan informasi kepada pihak lain, mendokumentasikan file-file, menyimpan datadata, dan lain-lain hingga mengambil sebuah keputusan penting bagi perusahaan. Secara prinsip, computer dan perangkat keras (hardware) lain hanyalah merupakan sebuah sumber daya fisik yang tidak dapat berfungsi tanpa ada manusia yang memberikan intruksi. Dalam hal ini, manusia membuat sebuah teknologi bernama perangkat lunak (software) yang pada dasarnya berisi suatu urutan intruksi untuk "menggerakan" berbagai komponen perangkat keras secara operasional. Dalam perkembangannya, software (perangkat lunak) dapat dibagi menjadi dua jenis besar, yaitu : Software yang berisi perintah-perintah atau seperangkat intruksi untuk mengoprasikan berbagai komponen hardware disebut sebagai System Software; dan Sofware yang berisi perintah-perintah untuk menjalankan suatu prosedur tertentu yang mempresentsikan proses, aktivitas, dan/atau fungsi bisnis tertentu disebut sebagai Application Software.

Semenjak diperkenalkannya setengah abad yang lalu, computer kerap didefinisikan sebagai "alat pengolah data" Hingga saat ini pun pengertian tersebut masih cukup relevan 
dipergunakan secara umum. Dengan menggunakan prinsip IPO (Input-Proses-Output), pengguna atau seseorang mengharapkan agar computer dapat menghasilkan output tertentu dari berbagai input yang diberikan. Jika dahulu bentuk bentuk pemrosesan hanya terbatas pada hal-hal semacam kalkulasi kuantitatif belaka dalam perkembangannya sekarang ini sebuah computer sudah dapat berfungsi sebagai alat bantu berbagai aktivitas kehidupan manusia, seperti; proses belajar, proses komunikasi, proses perdagangan, dan lain sebagainya.

Komputer menerima intruksi dari manusia untuk melakukan sejumlah pemrosesan data yang hasilnya akan dipresentasikan kepada yang bersangkutan. Untuk mengeti cara kerja komputer, perlu dipahami terlebih dahulu arsitektur dari perangkat keras ini. Sebuah computer standart dapat berkerja secara normal jika memiliki lima buah komponen sebagai berikut :

a. Input yang berfungsi untuk memeberikan perintah kepada computer dalam berbagai bentuk. Contoh dari alat input adalah papan ketik (keyboard), mouse, scanner, joystick. Dan lain sebagainya;

b. Alat output yang berfungsi untuk mempresentasikan hasil pemrosesan mempresentasikan hasil pemrosesan data atau hal-hal yang diinginkan. Termasuk di dalamnya adalah layar monitor, printer, plotter, dan lain sebagainya;

c. CPU atau Central Processing Unit yang merupakan pusat pengolahan dan kalkulasi data karena disinilah terletak chip mikroprosesor yang merupakan otak dan pusat syaraf komputer;

d. Memeori utama (primary memory) adalah sebuah modul di dalam computer tempat program dan intruksi aturan-aturan pengoprasian computer (sistem operasi) disimpan sementara (sebagaian bersifat permanen), ada dua jenis memory utama di dalam komputer, yaitu ROM (Ready Only Memory) yang menyimpannya bersifat sementara.

e. Media penyimpan atau memory skunder (secondary memory) yang bersifatnya semi pramanen untuk meletakkan data dan/atau program yang dibutuhkan oleh pengguna. Termasuk di dalam contoh media penyimpanan internal adalah harddisk dan media penyimpanan eksternal adalah diskette, compact disc (CD-ROM), zip disk, dan lain sebagainya.

Tugas Manajer dalam perusahaan dan hubungannya dengan Teknologi Informasi, Secara garis bersar, sehubungan dengan teknologi informasi, SDM diperusahaan dapat dibagi menjadi dua kelompok besar. Kelompok adalah kumpulan dari mereka yang merupakan para pengguna (user) teknologi informasi yang dimiliki. Termasuk di dalam kelompok ini seluruh jenjang SDM dari staf sampai dengan pimpinan puncak. Seluruh SDM ini dalam kesehariannya terlibat langsung dalam penggunaan teknologi informasi sebagai sarana penunjang dan pendukung aktivitas perkerjaan mereka sehari-hari kelompok kedua adalah mereka yang bertanggung jawab terhadap perencanaan dan pengembangan teknologi informasi di perusahaan. Tugas utama dari mereka yang berada di dalam kelompok ini adalah :

1) Menyusun perencanaan strategi (masterplan)mengenai perkembangan sistem dan teknologi informasi perusahaan, lengkap dengan cetak birunya (blue print)

2) Mendefinisikan secara detail kebutuhan sistem informasi perusahaan, terutama kebutuhan spesifik dari masing-masing individu yang ada

3) Menyediakan teknologi informasi yang sesuai dengan kebutuhan detail yang telah didefinisiskan tersebut 
4) Memelihara dan mengembangkan teknologi informasi yang dimiliki perusahaan agar selalu up-to-date dan dapat dipergunakan oleh seluruh perusahaan (vendor) yang berkerja sama dalam hal pengembangan teknologi

5) Mengolah hubungan kementrian dengan pihak - pihak di luar perusahaan (vendor) yang berkerja sama dalam hal pengembangan asset teknologi informasi

6) Memonitor dan mengawasi berbagai hal terkait dengan manajemen atau proses pengelolaan asset teknologi informasi.

Untuk menjalankan serangkaian tugas tersebu, biasanya dikenal berbagai jabatan profesional, seperti; chief executive officer, information technology manager system analyst, programmer, project manager, dan lain sebagainya yang masing-masing memiliki kompetensi dan keahlian khusus sehubung dengan teknologi informasi.

Kelompok kedua yang dimaksudkan dalam penjelasan diatas adalah para manajer dalam perusahaan. Agar tugas para amanajer tersebut dapat berjalan dengan baik, dengan cepat, akurat dan dapat dipertanggung jawabkan, maka diperlukan berbagai informasi. Infornasi yang diperlukan dalam hal ini adalah informasi yang telah yang telah diolah sedemikian rupa melalui sistem informasi manajemen akan sangat berarti apabila didukung oleh teknologi computer yang sudah sangat canggih perkembangannya.

Tanggung jawab manajer dalam Teknologi Informasi bagi perusahaan-perusahaan beesar yang kinerjanya sangat bergantung pada kehadiran teknologi informasi memiliki seorang manajer eksekutif di bidang sistem informasi.

Eksekutif yang paling bertanggung jawab terhadap perencanaan dan pengembangan technology informasi di perusahaan ini dikenal sebagai CIO (Chief Information Officer) atau Manajer Senior di bidang sistem dan teknologi information. Kalau di dalam format PT (Perusahaan Terbatas ) di Indonesia, CIO kurang lebih setara dengan direktur (dalam jajaran direksi perusahaan) yang langsung bertanggung jawab kepada presiden Direktur. Apakah tugas dari seseorang CIO ? Tugas Utama yang merupakan tanggung jawab eksekutif lain dalam jajaran direksi adalah mempelajari dan memahami secara menyeluruh dan mendetail bisnis yang digeluti perusahaan. Kalau dahulu manajemen inti cukup mempelajari semua komponen internal perusahaan (khususnya sehubungan dengan produki-produk atau jasa yang ditawarkan ), saat ini hal tersebut tidaklah cukup.

\section{Peran SIM bebasis Komputer dalam Pengambilan Keputusan}

Nilai suatu informasi berhubungan dengan keputusan. Dimana dukungan sistem informasi manajemen pada pembuatan keputusan dalam suatu organisasi dapat diuraikan menurut tiga tahapan, proses pembuatan keputusan, yaitu pemahaman, perancangan (design), dan pemilihan. Dukungan SIM biasanya melibatkan pengolahan, file computer maupun non computer. Pada tahap pemahaman hubungannya dengan SIM adalah pada proses penyelidikan yang meliputi pemeriksa data baik dengan cara yang telah ditentukan maupun dengan cara khusus SIM harus memberikan kedua cara tersebut. Sistem Informasi sendiri harus meneliti semua data dan mengajukan permintaan untuk diuji mengenai situasi-situasi yang jelas menuntut perhatian . baik SIM maupun organisasi harus menyediakan saluran komunikasi untuk masalah-masalah tersebut dapat ditanda tangani. Pada tahap ini juga perlu ditetapkan kemungkinan-kemungkinannya. Dukungannya SIM memerlukan suatu data base dengan data masyarakat. Saingan dan intem ditambah metode untuk penelusuran dan penemuan masalah-masalah. 
Pada tahap perancangan (design), kaitannya dengan SIM adalah membuat modelmodel keputusan untuk diolah berdasarkan data yang ada serta memprakarsainya pemecahanpemecahan alternatif. Model-model yang tersedia harus membantu menganalisis alternatifalternatif. Dukungan SIM terdiri dari perangkat lunak statistic serta perangkat lunak pembuatan model lainnya. Hal ini melibatkan pendekatan terstruktur, manipulasi model, dan sistem pencarian kembali data base.

Pada tahap pemilihan, SIM menjadi paling efektif apabila hasil-hasil perancangan disajikan dalam suatu bentuk yang mendorong pengambilan keputusan. Apabila telah dilakukan pemilihan, maka peranan SIM berubah menjadi pengumpulan data untuk umpan balik dan penilaian kemudian. Dukungan SIM untuk pembuatan keputusan terdiri dari suatu database yang lengkap, kemampuan pencarian kembali database yang lengkap, kemampuan pencarian kembali database, peranngkat lunak statiska dan analitik lainnya, serta suatu dasar model yang berisi perangkat lunak pembuatan model-model keputusan.

Hal tersebut berarti bahwa bila tidak ada pilihan atau keputusan, informasi menjadi tidak diperlukan. Keputusan dapat berkisar dari keputusan berulang yang sederhana sampai keputusan strategis jangka panjang. Sedangkan parameter untuk mengukur nilai sebuah informasi tersebut menurut Wahyono (2003), ditentukan dari dua hal pokok yaitu manfaat (benefit) dan biaya (soct). Suatu informasi dikatakan bernilai bila manfaatnya lebih efektif dibandingkan dengan biaya untuk mendapatkannya dan sebagai besar informasi tidak dapat tepat ditaksir keuntungannya dengan satuan nilai uang, tetapi dapat ditaksir nilai efektivitasnya. Dapat pula dikatakan bahwa pengukuran nilai sebuah informasi akan lebih tepat jika menggunakan analisis cost effectiveness atau cost benefit.

\section{Kesimpulan}

Berdasarkan uraian yang telah dijelaskan diatas sangatlah jelas bahwa hadirnya teknologi komputer telah memberikan kontribusi yang sangat positif dalam sistem informasi manajemen dan SIM juga sangat dibutuhkan oleh para pemimpin dalam suatu organisasi atau perusahaan untuk pengambilan keputusan yang dapat dipertanggung jawabkan. Bagi manajer, kehadiran komputer dalam SIM bukan saja memberikan kontribusi positif, lebih jauh dari pada itu, proses pengambilan keputusan menjadi lebih mudah, murah, dan dapat dipertanggung jawabkan.

Dengan adanya SIM berbasis komputer dapat menyajikan informasi bernilai dan berkualitas, yaitu relevan bagi perusahaan/organisasi, yang akurat dan tentu saja informasi yang tepat waktu. Bukan hanya itu saja dengan aktivitas SIM berbasis komputer ini, para pimpinan perusahaan/manajer dapat lebih mudah, murah, efisien dan efektif dalam upaya pengambilan keputusan, termasuk didalamnya dalam melalukan fungsi-fungsi manajemen, seperti perencanaan (planning), pengorganisasian (organizing), penggerakan (actuating), dan pengawasan (controlling) yang hasil keputusannya tersebut harus dapat dipertanggung jawabkan.

\section{Referensi}

[1]http;//s3.amazonaws.com/ppt-dowload/peran-sistem-informasi-manajemen-dalam pengambilan-keputusan-organisasi-123484669287089-2.doc

[2] http;//kataloq.library.perbanas.ac.id/download 3922. Rangkuman, pdf 
[3]Charnes, A. dan Chooper, W.W. (1978). Managerial Economics; Past, Presen and

Future Journal of Enterprise Management. Volume 1. Issue 1.Hal. 5-23

[4] Odgers, P. (2005). Administrative Office Managemen, Edisi Ketigabelas. Thomson; South-Westen

[5] warsidi,Adi, Administrasi Perkantoran, 1999, Universitas Terbuka

[6] http;//www.scribd.com.doc/8336496/Analisis-peran-informasi-Manajemen-Berbasis Komputer-Dalam Proses-Pengambilan

[7] Hartono, Bambang. 2013. Sistem Informasi Manajemen Berbasis Komputer. Jakarta:Rineka Cipta.

[8] Komputer, Wahana. 2012. Membangun Web Interaktif dengan Adobe DreamweaverCS5.5, PHP, dan MySQL. Yogyakarta: Andi.

[9] Komputer, Wahana. 2013. Adobe Dreamweaver CS6. Yogyakarta: Andi.

[10] Kristanto, Andri. 2008. Perancangan Sistem Informasi dan Aplikasinya. Yogyakarta:Gava Media.

[11] Ladjamudin, Bin Al-Bahra. 2013. Analisis dan Desain Sistem Informasi. Yogyakarta:Graha Ilmu.

[12] Madcoms. 2013. Mahir dalam 7 Hari Adobe Dreamweaver CS6 denganPemrograman PHP \& MySQL. Yogyakarta: Andi.

[13] Mursid. 2014. Manajemen Pemasaran. Jakarta: Bumi Aksara.

[14] Nugroho, Bunafit. 2013. Dasar Pemrograman Web PHP - MySQL dengan Dreamweaver. Yogyakarta: Gava Media.

[15] Phoenix, Tim Pustaka. 2009. Kamus Besar Bahasa Indonesia Edisi Baru. Jakarta: PTMedia Pustaka Phoenix.

[16] Sutabri, Tata. 2012. Analisis Sistem Informasi. Yogyakarta: Andi. Sutarman. 2012. Pengantar Teknologi Informasi. Jakarta: Bumi Aksara. Waluyo. 2008. Akuntansi Pajak. Jakarta: Salemba Empat. 